\title{
Liver Diet in Hepatic Encephalopathy Patients
}

\author{
Choirina Windradi, Iswan Abbas Nusi, Poernomo Boedi Setiawan, Herry Purbayu, Titong \\ Sugihartono, Ummi Maimunah, Ulfa Kholili, Budi Widodo, Muhammad Miftahussurur, Husin \\ Thamrin and Amie Vidyani \\ Department of Internal Medicine, Faculty of Medicine, Universitas Airlangga, Dr. Soetomo General Hospital, Jl. Prof dr. \\ Moestopo 47 Surabaya 60132, Indonesia \\ apji@fk.unair.ac.id
}

Keywords: Hepatic Encephalopathy, Malnutrition, Nutrient Intake.

\begin{abstract}
Hepatic encephalopathy (HE) is the most common complication, and one of the complicating manifestations of liver disease. Malnutrition is the most common complication of liver failure. Furthermore, it is a prognostic factor (survival rate, length of stay in hospitals and life quality) in cirrhosis patients. The primary concept of HE pathogenesis is intestine-derived nitrogen compounds that affect brain function. Daily protein intake is a key in HE pathogenesis; therefore, HE patients need nutrient intake in addition to medication.
\end{abstract}

\section{INTRODUCTION}

Hepatic encephalopathy (HE) is the most common complication, and one of the complicating manifestations of liver disease. The greatest challenge is there is no universally accepted standard for $\mathrm{HE}$ management, particularly major nutrient management, due to the lack of clinical research. This is a less favorable situation for patients, whereas many serious complications are caused by cirrhosis (Frederick, 2011).

Malnutrition is the most common complication of liver failure. Furthermore, it is a prognostic factor (survival rate, length of stay in hospitals and life quality) in cirrhosis patients. Malnutrition incidence in cirrhosis ranges from $65-90 \%$. This is due to nutritional metabolism disorders occurring in the liver, such as increased protein catabolism, increased branched-chain amino acid (BCAA) usage, decreased ureagenesis, decreased glycogen synthesis of muscle and liver, increased gluconeogenesis, increased glucose intolerance and insulin resistance, increased lipolysis, free fatty acid oxidation and increased ketogenesis (Ndraha, Hasan, \& Simadibrata, 2011).

The primary concept of $\mathrm{HE}$ pathogenesis is intestine-derived nitrogen compounds that affect brain function. Theoretically, neurotoxins are believed to enter the intestine's systemic circulation through the brain barrier, where neurotoxin alters astrocytes' function and morphology. A number of neurotoxins, such as ammonia, gamma-aminobutyric acid-ergic (GABA-ergic), catecholamine pathways and false neurotransmitters, have been shown to play a role in experimental HE (Cabral \& Burns, 2011). Various studies have argued that ammonia, derived from daily protein intake, is a key in HE pathogenesis. Therefore, HE therapy is based on suppressing predisposing factors and decreasing ammonia production. The production of intestinal ammonia can be suppressed through protein intake restriction and lactulose administration which may inhibit bacteria producing urease-inhibited enzyme (Nguyen \& Morgan, 2014).

\section{PATHOGENESIS}

The pathophysiology of hepatic encephalopathy has been formulated on accumulation in various toxins in the patient's bloodstream and brain. Ammonia is believed to be the key molecule causing HE (Frederick, 2011). Increased ammonia production in the body has long been suspected to originate from bacteria colonization that have urease enzyme activity, gram-negative anaerobes, Enterobacteriaceae, proteus and clostridium. Bacterial urease will break down urea coming from the bloodstream into ammonia and carbon dioxide. 
When ammonia is produced by enterocytes and bacteria in the colon, ammonia moves through the splanchnic vein system to liver for detoxification which generally occurs through the urea cycle within a hepatocyte zone and through glutamine changes in the three-hepatocyte zone (Hasan, 2014).

Kidneys can also produce ammonia through glutamine metabolism via glutaminase into ammonia, bicarbonate and glutamate. This ammonia formation acts as an acid-base homeostasis since bicarbonate is also produced in the cycle; ammonia genesis can be an acidosis buffer system (Frederick, 2011).

\section{DIAGNOSIS}

Hepatic encephalopathy produces a broad spectrum of non-specific neurologic and psychiatric manifestations. The HE diagnosis may refer to West Haven criteria of dividing HE based on its symptom degree as seen in Table 1 (Hasan, 2014).

Table 1: West Haven criteria.

\begin{tabular}{cll}
\hline Degree & \multicolumn{1}{c}{$\begin{array}{c}\text { Cognitive and } \\
\text { behavior }\end{array}$} & \multicolumn{1}{c}{$\begin{array}{c}\text { Neuromuscular } \\
\text { function }\end{array}$} \\
\hline 0 & $\begin{array}{l}\text { Asymptomatic } \\
\text { Sleep disorder, } \\
\text { decreased } \\
\text { concentration, } \\
\text { anxiety and } \\
\text { irritability }\end{array}$ & $\begin{array}{l}\text { None } \\
\text { Monotonous sound, } \\
\text { tremor, decreased } \\
\text { writing ability }\end{array}$ \\
2 & $\begin{array}{l}\text { Lethargy, } \\
\text { disorientation, } \\
\text { memory loss } \\
\text { Somnolen, } \\
\text { confusion, amnesia, } \\
\text { emotional distress }\end{array}$ & $\begin{array}{l}\text { Ataxia, dysaxia } \\
\text { Nystagmus, muscle } \\
\text { stiffness, } \\
\text { hyperreflexia or } \\
\text { hyporeflexia } \\
\text { Dilated pupils, } \\
\text { pathological reflexes }\end{array}$ \\
\hline
\end{tabular}

\section{NUTRIENTS}

Energy requirements vary in liver cirrhosis patients. In general, the energy requirement of patients with end-stage hepatic disease is around $120-140 \%$ of basic energy requirements. The energy requirement increases to $150-175 \%$ if there is ascites, infection, or malabsorption (Idris, 2013).

Cirrhosis patients also experience increased protein usage. A study suggested that the average protein requirement to obtain nitrogen balance is 0.8 grams $/ \mathrm{kg} /$ day in cirrhosis patients. On the other hand, the average protein requirement for hepatitis or cirrhosis patients without encephalopathy ranges from $0.8-1 \mathrm{gram} / \mathrm{kg} / \mathrm{day}$. The patient requires nitrogen consumption of $1.2-1.3$ grams $/ \mathrm{kg} / \mathrm{day}$ to obtain a positive balance. The protein consumption is up to 1.5 grams $/ \mathrm{kg} /$ day under stress conditions such as alcohol hepatitis, sepsis, infection, gastrointestinal bleeding and ascites (Idris, 2013).

A prospective randomized control study was conducted to examine protein intake differences in cirrhotic patients. Among the 62 cohort patients, 15 patients received normal protein intake and 15 patients did not receive protein intake. Patients with low protein did not receive protein for three days, before the protein intake was raised to $1.2 \mathrm{~g} / \mathrm{kg} / \mathrm{day}$. On the other hand, patients with normal protein received a standard protein intake of $1.2 \mathrm{~g} / \mathrm{kg} /$ day. At the end of the study, synthesis and protein degradation were similar in both groups. Biochemical data (including ammonia) and HE course were also similar in both groups (Cordoba et al., 2004; Nguyen \& Morgan, 2014).

Short-term protein restriction does not degrade total body protein or worsen clinical outcomes. In refractory HE cases, short-term protein restriction is more favorable and does not affect decreased body protein (Cordoba et al., 2004; Nguyen \& Morgan, 2014).

Not all HE patients need dietary protein restriction because short-term protein restriction does not cause any total body protein breakdown or severe clinical condition as protein restriction is only performed in HE patients for a short period of time. The type of protein consumed is as important as the amount of protein consumed (Cordoba et al., 2004; Nguyen \& Morgan, 2014). A study suggested that milk protein can be better tolerated than mixed proteins, and vegetable protein is better tolerated than animal protein (Riggio et al., 2003). Vegetable proteins contain more fiber protein than isonitrogenous animal protein. Fiber is able to increase food speed through intestines, causing increased excretion of fecal ammonia and decreasing intestinal luminal $\mathrm{pH}$. Compared to animal protein, vegetable protein has a lower amino acid content of methionine sulfate and cysteine, which is a mercaptan precursor and an indole or oxindole compound that serve as the main cause of HE. Vegetable proteins are rich in ornithine and arginine that facilitate ammonia discharge through the urea cycle (Deutz et al., 2014).

The American Association for the Study of Liver Diseases (AASLD) and the European Association 
for the Study of the Liver (EASL) recommend lactulose administration (A1) as a therapy for HE patients (Suk et al., 2012). Lactulose works by increasing non-urease bacteria growth, such as lactobacilli, and lowering intestinal $\mathrm{pH}$. Ammonia in the body is as ammonium ion (NH4+) and nonammonia ions (NH3). The ratio of this compound is determined by blood $\mathrm{pH}$. The more acidic the colonic environment increasing the $\mathrm{pH}$ gradient, the more the ammonia absorption decrease from the gut (Elkington, 1970). This procedure corresponds with protein restriction in HE patients which are the raw material of ammonia.

Delayed gastric emptying serves as one of mechanisms responsible for gastrointestinal complaints in hemorrhagic stroke (HS) patients. Gastric accommodation disorder is associated with a sense of satiety, bloating and epigastric pain (Kalaitzakis, 2014). Most HS patients with EH have dyspepsia, bloating, nausea and high-protein diet intolerance (Nusi, 2015).

Membrane hyper mealability is found in HS patients that subsequently causes HS patients to be more susceptible to spontaneous bacterial peritonitis. Small bowel motility disorder is also associated with intestinal bacteria growth that makes HS patients susceptible to infection (Kalaitzakis, 2014). Therefore, a high-protein diet is not recommended because it is believed to aggravate gastrointestinal symptoms and multiply intestinal bacteria.

It can be inferred that a high-protein diet is not recommended for $\mathrm{HS}$ patients with $\mathrm{EH}$ since protein restriction is believed to increase ammonia levels in the blood, and short-term protein restriction does not degrade total body protein or worsen clinical outcomes.

\section{HEPATIC ENCEPHALOPATHY DIET}

Decreased ammonia levels and HE clinical improvement are significant in the $\mathrm{HE}$ diet compared to normal proteins. A study found high BCAA content in a $\mathrm{HE}$ diet and supplementation with $\mathrm{BCAA}$ infusion on a $\mathrm{HE}$ diet can reduce ammonia without causing malnutrition that subsequently improves clinical HE (Nusi, 2015). Other studies found decreased ammonia levels and a significant clinical HE improvement after HE diet compared to a normal protein diet (Lesmana, 2014; Nusi, 2015).

The HE diet is divided into HE-3, HE-2 and HE1 diets. The HE- 3 diet contains a nutritional value of 1,200 calories $(10 \%$ protein, $42 \%$ fat, $48 \% \mathrm{KH}$ and branched-chain amino acid/aromatic amino acid (BCAA/AAA) ratio of 2.25). The HE 3-dietary form uses enteral administration (feeding tube or liquid). The HE-2 diet contains 1,516.7 calories, consisting of $12 \%$ protein, $33 \%$ fat, $55 \% \mathrm{KH}$ and BCAA/AAA ratio of 2.25. The food can be given orally (semiliquid). The HE-1 diet has a nutritional value of 1,577 calories ( $13 \%$ protein, $27 \%$ fat, $60 \% \mathrm{KH}$ and a BCAA/AAA ratio of 1.76). The dietary pattern includes soft foods plus vegetable and chopped protein. The HE diet provided at Dr. Soetomo General Hospital Surabaya, Indonesia, is presented in Table 2-3 (Nusi, 2015).

Along with scientific development, particularly in the diet for liver cirrhosis patients with HE, the results of consensus and the Indonesian Hepatic Encephalopathy Clinical Practice Guide published by the Indonesian Association for the Study of the Liver in 2014 advised revision of the protein intake level in the HE diet (Nusi, 2015). The HE diet has been revised based on empirical experience as most liver cirrhosis patients with HE have dyspepsia, bloating, nausea and high-protein diet intolerance.

Implementation of the HE diet at Dr. Soetomo General Hospital, Surabaya, Indonesia, in grade-IV hepatic coma patients is HE-3 diet $(1,200 \mathrm{~K})$ using a feeding tube. The HE-3 diet is still administered until the patient's hepatic coma improves to grade II, characterized by memory disorder, lethargy, dysarthria and flapping tremor in motoric evaluation. If the patient's awareness improves, but psychomotor function is still slow as evidenced by a bad result of $\mathrm{NCT}$, the HE-2 diet can be administered. The HE-2 diet is given when the patient is not in HE condition, followed by a hepatic diet when the patient is discharged from hospital. 
Table 2: The 2004 hepatic encephalopathy diet.

\begin{tabular}{lccccc}
\hline \multicolumn{1}{c}{ Type } & Calory & Protein & Administration & Indication & Parenteral addition \\
\hline $\begin{array}{l}\text { HE-1 diet } \\
(1700 \text { K } 30 P)\end{array}$ & $1,700 \mathrm{kcal}$ & $7 \%$ & Oral & Hepatic precoma & BCAA \\
$\begin{array}{l}\text { HE-2 diet } \\
\begin{array}{l}(1400 \text { K } 18 \mathrm{P}) \\
\text { HE-3 diet }\end{array}\end{array}$ & $1,400 \mathrm{kcal}$ & $5 \%$ & Oral & Hepatic precoma (I) & BCAA \\
\begin{tabular}{l}
$(1200$ K 4 P $)$ \\
\hline
\end{tabular} & $1,200 \mathrm{kcal}$ & $1 \%$ & Feeding tube & $\begin{array}{c}\text { Hepatic coma (II, } \\
\text { III, IV) }\end{array}$ & BCAA \\
\hline
\end{tabular}

Table 3: The 2015 hepatic encephalopathy diet

\begin{tabular}{|c|c|c|c|c|c|}
\hline Type & Calory & Protein & Administration & Indication & $\begin{array}{c}\text { Parenteral } \\
\text { addition }\end{array}$ \\
\hline $\begin{array}{l}\text { HE-1 diet } \\
(1577 \mathrm{~K})\end{array}$ & $1,577 \mathrm{kcal}$ & $13 \%$ & Oral & $\begin{array}{l}\text { Resolved hepatic } \\
\text { precoma }\end{array}$ & BCAA \\
\hline $\begin{array}{l}\text { HE-2 diet } \\
(1561,7 \mathrm{~K})\end{array}$ & $1,561.7 \mathrm{kcal}$ & $12 \%$ & Oral & Hepatic precoma (I) & BCAA \\
\hline $\begin{array}{l}\text { HE-3 diet } \\
(1200 \mathrm{~K})\end{array}$ & $1,200 \mathrm{kcal}$ & $10 \%$ & Feeding tube & $\begin{array}{c}\text { Hepatic coma (II, } \\
\text { III, IV) }\end{array}$ & BCAA \\
\hline
\end{tabular}

\section{SUMMARY}

Hepatic encephalopathy is the most common complication of cirrhosis. The current HE pathogenesis still holds that toxin causing HE is due to ammonia accumulation as a result of protein metabolism. Therefore, HE therapy is performed based on precipitant and protein intake restriction. Even though some studies have pointed out that normal protein administration cannot worsen the patient's clinical outcome, the most current consensus recommends short-term protein restriction for $\mathrm{HE}$ patients. These facts underlie $\mathrm{HE}$ diet preparation at Dr. Soetomo General Hospital Surabaya, Indonesia, and its dietary pattern has been applied since 2004 .

\section{REFERENCES}

Cabral, C. M., \& Burns, D. L. (2011). Low-protein diets for hepatic encephalopathy debunked: let them eat steak. Nutr Clin Pract, 26(2), 155-159. doi: 10.1177/0884533611400086

Cordoba, J., Lopez-Hellin, J., Planas, M., Sabin, P., Sanpedro, F., Castro, F., . . . Guardia, J. (2004). Normal protein diet for episodic hepatic encephalopathy: results of a randomized study. $J$ Hepatol, 41(1), 38-43. doi: 10.1016/j.jhep.2004.03.023

Deutz, N. E., Bauer, J. M., Barazzoni, R., Biolo, G., Boirie, Y., Bosy-Westphal, A., . . . Calder, P. C. (2014). Protein intake and exercise for optimal muscle function with aging: recommendations from the ESPEN Expert Group. Clin Nutr, 33(6), 929-936. doi: 10.1016/j.clnu.2014.04.007
Elkington, S. G. (1970). Lactulose. Gut, 11(12), 10431048.

Frederick, R. T. (2011). Current concepts in the pathophysiology and management of hepatic encephalopathy. Gastroenterol Hepatol (N Y), 7(4), 222-233.

Hasan, I., Araminta, A. P. (2014). Ensefalopati Hepatik: Apa, Mengapa dan Bagaimana? . Medicinus, 27, 1-8.

Idris, S. M., Ali, E. A. (2013). Assessment of Dietary Management of Patients with Cirrhosis Liver. International Journal of Science and Research, 2, 47 53.

Kalaitzakis, E. (2014). Gastrointestinal dysfunction in liver cirrhosis. World J Gastroenterol, 20(40), 1468614695. doi: 10.3748/wjg.v20.i40.14686

Lesmana, L., Nusi, I. A., Gani, R. A., Hasan, I., Sanityoso, A., Lesmana R. A., Siregar, L., Setiawan, P. B., Bayupurnama, P., Purnomo, H. D. (2014). Panduan Praktik Klinik Ensefalopati di Indonesia. . Jakarta, Indonesia: PPHI.

Ndraha, S., Hasan, I., \& Simadibrata, M. (2011). The effect of L-ornithine L-aspartate and branch chain amino acids on encephalopathy and nutritional status in liver cirrhosis with malnutrition. Acta Med Indones, 43(1), 18-22.

Nguyen, D. L., \& Morgan, T. (2014). Protein restriction in hepatic encephalopathy is appropriate for selected patients: a point of view. Hepatol Int, 8(2), 447-451. doi: 10.1007/s12072-013-9497-1

Nusi, I. A. (2015). Diet Hati: Buku Ajar Ilmu Penyakit Dalam Fakultas Kedokteran Universitas Airlangga Rumah Sakit Pendidikan Dr. Soetomo Surabaya Edisi2. Surabaya, Indonesia: Airlangga University Press.

Riggio, O., Angeloni, S., Ciuffa, L., Nicolini, G., Attili, A. F., Albanese, C., \& Merli, M. (2003). Malnutrition is not related to alterations in energy balance in patients with stable liver cirrhosis. Clin Nutr, 22(6), 553-559.

Suk, K. T., Baik, S. K., Yoon, J. H., Cheong, J. Y., Paik, Y. H., Lee, C. H., . . . Korean Association for the 
Study of the, L. (2012). Revision and update on clinical practice guideline for liver cirrhosis. Korean $J$ Hepatol, 18(1), 1-21. doi: 10.3350/kjhep.2012.18.1.1 